\title{
ИСПОЛЬЗОВАНИЕ СРЕДСТВ СКАЗКОТЕРАПИИ В ПРОЦЕССЕ ФОРМИРОВАНИЯ СВЯЗНОЙ РЕЧИ У МЛАДШИХ ШКОЛЬНИКОВ С РЕЧЕВЫМИ НАРУШЕНИЯМИ'
}

\section{THE USE OF FAIRY TREATMENT MEANS IN THE PROCESS FORMATION OF CONNECTED SPEECH IN YOUNGER SCHOOL CHILDREN WITH SPEECH DISORDERS}

\section{S. Inevatkina}

E. Kasimova

Summary: The article discusses the issues related to the process of improving coherent speech in primary schoolchildren with speech disorders. The results of the diagnostic study are presented. The level of formation of coherent speech and cognitive development in primary schoolchildren with speech disorders is characterized. It is about using the means of fairy tale therapy. The results of the dynamics of the advancement of primary schoolchildren with speech disorders in the formation of coherent speech by means of fairy tale therapy are described.

Keywords: coherent speech, fairy tale therapy, younger students, speech disorders on.
Иневаткина Светлана Евгеньевна

К.псх.н., доцент, Мордовский государственный педагогический университет им. М.Е. Евсевьева, г. Саранск svetlaj23@mail.ru

Касимова Екатерина Алексеевна

Мордовский государственный педагогический университет им. М.Е. Евсевьева, г. Саранск

Аннотация: В статье рассматриваются вопросы, связанные с процессом совершенствования связной речи у младших школьников с речевыми нарушениями. Приводятся результаты диагностического исследования. Характеризуется уровень сформированности связной речи и познавательного развития у младших школьников с речевыми нарушениями. Говорится 06 использовании средств сказкотерапии. Описываются результаты динамики продвижения младших школьников с речевыми нарушениями в формировании связной речи средствами сказкотерпии.

Ключевые слова: связная речь, сказкотерапия, младшие школьники, речевые нарушения.
$M$ ноголетняя практика Российского образования показывает целесообразность современных подходов, при реализации которых удается максимально реализовать потенциал ребенка. Определенные сложности возникают при обучении и воспитании младших школьников с ограниченными возможностями здоровья. В данном контексте особое место занимают обучающиеся с речевыми нарушениями. С одной стороны, младшие школьники с речевыми нарушениями относятся к категории обучающихся с ограниченными возможностями здоровья и имеют определенные дефициты, с другой стороны, возможности обучающихся с речевыми нарушениями близки к таковым нормально развивающихся сверстников. Соответственно, при грамотно организованном процессе сопровождения младшие школьники с речевыми нарушениями могут достигнуть результатов наравне со сверстниками, которые не имеют ограниченные возможности здоровья [2; 3; 10].

Среди обучающихся указанной категории большин- ство младших школьников не способны ясно, точно и выразительно сформулировать и высказывать свои мысли. Сложности возникают не только в процессе рассуждения, но и в процессе фантазирования. В учебной деятельности трудности возникают при выполнении учебных действий, а именно при восприятии и воспроизведении учебных текстовых заданий, при формулировании развернутых ответов на вопросы. Все указанные особенности связаны с низким уровнем сформированности связной речи, что в свою очередь затрудняет развитие устной, письменной речи и процесс адекватного восприятия учебного материала.

Проблема изучения связной речи поднималась в работах отечественных исследователей Е.В. Емец, А.В. Кочетковой, Р.Е. Левиной, М.В. Хализевой $[4 ; 6 ; 7 ; 11]$. Связная речь - это развёрнутое высказывание, построенное в адекватной логической последовательности с тематически связанными частями. Данная речь обладает такими свойствами как: самостоятельность и законченность

Исследование выполнено в рамках сетевого гранта ФГБОУ ВО Мордовского государственного педагогического института им. М.Е. Евсевьева и ФГБОУ ВО «Чувашский государственный педагогический университет им. И.Я. Яковлева» по теме «Психоло-

го-педагогическое сопровождение лиц с ограниченными возможностями здоровья». 
[7, c. 64].

Для успешной социализации и дальнейшего развития младших школьников с речевыми нарушениями необходимо сформировать коммуникативную функцию связной речи, которая обеспечивает общение и процесс взаимодействия с окружающими; когнитивную функцию связной речи, благодаря которой происходит постижение окружающей действительности и осуществление мыслительных операций; регулятивную функцию связной речи, которая позволяет осуществлять планирование и контроль деятельности. Указанные функции подробно описаны в работах Н.С. Шарафутдиновой $[12$, с. 47].

Одним из эффективных средств формирования указанных функций у младших школьников с речевыми нарушениями является сказкотерапия. В.И. Бутова, В.А. Дегальцева, С.И. Игнатьева, Е.А. Мишакина, Г.А. Морозько отмечают, что сказкотерапия способствует развитию воображения и повышению уровня сформированности связной речи $[1 ; 5 ; 8 ; 9]$.

Опытно-экспериментальная работа проводилась на базе МБОУ «Средняя общеобразовательная школа с углубленным изучением отдельных предметов № 32»г. о. Саранск и МБОУ «Средняя общеобразовательная школа № 8» г. о. Саранск. В качестве испытуемых выступили младшие школьники с общим недоразвитием речи, обучающиеся во 2 классе. Учащиеся МБОУ «Средняя общеобразовательная школа с углубленным изучением отдельных предметов № 32» г. о. Саранск (11 обучающихся второго класса) составили экспериментальную группу, а учащиеся «Средняя общеобразовательная школа № 8» г. о. Саранск (11 обучающихся второго класса) выступили в качестве контрольной группы.

В первую очередь был реализован констатирующий эксперимент, целью которого было изучение уровня сформированности связной речи у младших школьников с речевыми нарушениями. Констатирующий эксперимент был реализован в два этапа. На первом этапе был исследован уровень связной речи, а именно изучен уровень сформированности умения последовательно описывать предмет и человека; уровень сформированности умения осуществлять повествование; уровень сформированности умения рассуждать. В качестве диагностического инструментария были использованы следующие методики: «Описание заданного предмета», «Описание изображения человека на фотографии», «Повествование по картинке», «Повествование по заданной теме», «Рассуждение по картинке», «Рассуждение по заданной теме». На втором этапе был исследован уровень сформированности познавательных способностей. В качестве диагностического инструментария использовались следующие задания: «Обобщение», «Исключение лишнего», «Парные аналогии».
Данные констатирующего эксперимента показали, что уровень сформированности связной речи, а именно умения последовательно описывать предмет и изображение человека, умения осуществлять повествование, умения рассуждать, а также познавательная способность устойчиво сохранять заданный способ рассуждений при решении ряда разнообразных задач у младших школьников с речевыми нарушениями находятся преимущественно на низком уровне. Познавательные способности, а именно способность обобщать, умение находить общее в предметах и явлениях, умение выражать найденное общее в виде конкретного понятия, способность к классификации и анализу, умение определять логические связи между понятиями - преимущественно на среднем уровне.

Следующим этапом опытно-экспериментальной работы был проведен формирующий эксперимент, целью которого стало повышение уровня сформированности связной речи у младших школьников с речевыми нарушениями. В данном эксперименте приняли участие только испытуемые экспериментальной группы.

В формате данной работы особое внимание уделялось устной речи, а именно формированию монологической речи: описанию, повествованию и рассуждению. При организации формирующего эксперимента учитывались следующие критерии связности устного сообщения: смысловые связи между частями текста; логические и грамматические связи между предложениями; связи между частями предложения; законченность выражения мысли говорящего; последовательность изложения.

Для проведения формирующего эксперимента была предложена программа занятий и методические рекомендации к ней. При составлении программы, сказкотерапия рассматривалась как интегрированная деятельность, в которой действия воображаемой ситуации связаны с реальным общением, направленным на активность, самостоятельность, творчество, регулирование младшим школьником собственных эмоциональных состояний. Важность такого понимания заключается в том, что уровень сформированности и качество связной речи коррелирует с особенностями эмоционального состояния младшего школьника, его заинтересованностью и сформированными речевыми привычками. Процесс формирования и развития связной речи зависит от уровня самостоятельности, активности, произвольности, эмоциональности, креативности (способности к творчеству) младшего школьника с речевыми нарушениями. Указанные качества личности могут быть сформированы при использовании сказкотерапии. Кроме того, особое внимание уделялось использованию сказкотерапии в работе над нарушениями логической последовательности при изложении материала, употреблением однотипных связей, в многочисленном присутствии элементов ситуативности, пауз, лишних движений и лексической невыразительности. 
Непосредственно образовательная деятельность с применением средств сказкотерапии может быть представлена несколькими этапами реализации: организационный этап; этап использования средств сказкотерапии; этап демонстрации сочиненных сказок. Основные приемы формирования связной речи у младших школьников с речевыми нарушениями, используемые в нашей работе - это пересказ; составление различных рассказов (составление рассказов с картинным материалом, в том числе рассказ-описание, рассказ-рассуждение).

Следующим этапом был проведен контрольный эксперимент. Его цель - выявление динамики продвижения младших школьников с речевыми нарушениями в формировании связной речи. Результаты контрольного эксперимента, показали наличие положительной динамики у испытуемых экспериментальной группы: значительно повысился уровень сформированности связной речи и уровень сформированности познавательных способностей. Большинство младших школьников с речевыми нарушениями, которые приняли участие в формирующем эксперименте, демонстрировали средний уровень сформированности умения последовательно описывать предмет и изображение человека, умения осуществлять повествование, умения рассуждать. Также большинство испытуемых экспериментальной группы демонстрировали средний уровень сформированности способности устойчиво сохранять заданный способ рассуждений при решении ряда разнообразных задач, способности обобщать, умения находить общее в предметах и явлениях, умения выражать найденное общее в виде конкретного понятия, способности к классификации и анализу, умения определять логические связи между понятиями. У младших школьников с речевыми нарушениями из контрольной группы, результаты по сравнению с констатирующим экспериментом остались на прежнем уровне.

Таким образом, предложенная программа формирования связной речи у младших школьников с речевыми нарушениями средствами сказкотерапии позволила повысить эффективность логопедических занятий, сократить время, затрачиваемое на формирование и развитие связной речи у испытуемых указанной категории, повысить уровень сформированности познавательных способностей и регулятивных навыков. Результаты контрольного эксперимента доказали эффективность предложенной программы, которая может быть рекомендована для использования в деятельности учителя-логопеда при формировании, развитии и коррекции связной речи.

\section{ЛИТЕРАТУРА}

1. Бутова, В.И. Применение сказкотерапии логопедом в процессе коррекционной работы / В.И. Бутова, В.А. Дегальцева. // Современное образование: актуальные вопросы, достижения и инновации: сборник статей ХІІІ Международной научно-практической конференции - 2018. - С. 254-256.

2. Гамаюнова, А.Н. Индивидуальный образовательный маршрут как условие удовлетворения особых образовательных потребностей обучающихся с ограниченными возможностями здоровья в инклюзивной практике / А.Н. Гамаюнова // Современные исследования социальных проблем. - 2017. Tом 8. - № 1-2. - C. 35-43.

3. Золоткова, Е.В. Коррекционно-развивающая работа в сенсорной комнате с детьми с ограниченными возможностями здоровья / Е.В. Золоткова, С.Е. Иневаткина // Гуманитарные науки. - 2014. - № 4. - С. 31-35.

4. Емец, Е.В. Особенности связной речи у младших школьников с общим недоразвитием речи / Е.В. Емец // Специальное 0бразование - 2017. - Т.2 C. 40-42.

5. Игнатьева, С.И. Использование элементов сказкотерапии и здоровьесберегающих технологий на логопедических занятиях / С.И. Игнатьева // Образование и воспитание. -2020 . - № 1. - С. 8-11.

6. Кочеткова А.В. Комплексные методы развития связной речи младших школьников / А.В. Кочеткова // Начальная школа. - 2002. - №9. - С. 64-68.

7. Левина, Р.Е. Основы теории и практики логопедии / Р.Е. Левина. - Москва: Просвещение, 1968. - 105 с. - Текст : непосредственный.

8. Мишакина, Е.А. Применение сказкотерапии в коррекции речевых нарушений у детей с тяжелыми нарушениями речи / Е.А. Мишакина // Вопросы дошкольной педагогики. - 2017. - №4 (10) - С. 44-46.

9. Морозько, Г.А. Использование элементов сказкотерапии в логопедической работе с детьми младшего школьного возраста с ЗПР / Г.А. Морозько // Наука и образование: новое время - 2015. - №6 (11) - С. 396-401.

10. Рябова, Н.В. Современное состояние инклюзивного образования / Н.В. Рябова, Т.А. Парфенова, 0.Е. Ефимова // В мире научных открытий. - 2015. № $5.3(65)$. - C. $995-1006$.

11. Хализева, М.В. Характеристика речевого развития младших школьников / М.В. Хализева // Актуальные проблемы гуманитарных и естественных наук. - Москва: научно-информативный издательский центр и редакция журнала «Актуальные проблемы гуманитарных и естественных наук», 2015. № 11-2. - С. 196-198.

12. Шарафутдинова, Н.С. Теория и история лингвистической науки / Н.С. Шарафутдинова - Ульяновск: Ульяновский государственный технический университет, 2006. - 284 c. - ISBN 5-89146-910-3

\section{(c) Иневаткина Светлана Евгеньевна (svetlaj23@mail.ru), Касимова Екатерина Алексеевна.}

Журнал «Современная наука: актуальные проблемы теории и практики» 